\title{
The viral protein NSP1 acts as a ribosome gatekeeper for shutting down host translation and fostering SARS-CoV-2 translation
}

\author{
ANTONIN TIDU, ${ }^{1}$ AURÉLIE JANVIER, ${ }^{1}$ LAURE SCHAEFFER, ${ }^{1}$ PIOTR SOSNOWSKI, ${ }^{1}$ LAURIANE KUHN, ${ }^{2}$ \\ PHILIPPE HAMMANN, ${ }^{2}$ ERIC WESTHOF, ${ }^{1}$ GILBERT ERIANI, ${ }^{1}$ and FRANCK MARTIN ${ }^{1}$ \\ ${ }^{1}$ Université de Strasbourg, Institut de Biologie Moléculaire et Cellulaire, "Architecture et Réactivité de l'ARN" CNRS UPR9002, F-67084 \\ Strasbourg, France \\ ${ }^{2}$ Institut de Biologie Moléculaire et Cellulaire, Plateforme Protéomique Strasbourg—Esplanade, CNRS FRC1589, Université de Strasbourg, \\ F-67084 Strasbourg, France
}

\begin{abstract}
SARS-CoV-2 coronavirus is responsible for the Covid-19 pandemic. In the early phase of infection, the single-strand positive RNA genome is translated into nonstructural proteins (NSP). One of the first proteins produced during viral infection, NSP1, binds to the host ribosome and blocks the mRNA entry channel. This triggers translation inhibition of cellular translation. Despite the presence of NSP1 on the ribosome, viral translation proceeds, however. The molecular mechanism of the so-called viral evasion to NSP1 inhibition remains elusive. Here, we confirm that viral translation is maintained in the presence of NSP1 and we show that the evasion to NSP1-inhibition is mediated by the cis-acting RNA hairpin SL1 in the 5'UTR of SARS-CoV-2. Only the apical part of SL1 is required for viral translation. We further show that NSP1 remains bound on the ribosome during viral translation. We suggest that the interaction between NSP1 and SL1 frees the mRNA accommodation channel while maintaining NSP1 bound to the ribosome. Thus, NSP1 acts as a ribosome gatekeeper, shutting down host translation and fostering SARS-CoV-2 translation in the presence of the SL1 5'UTR hairpin. SL1 is also present and necessary for translation of subgenomic RNAs in the late phase of the infectious program. Consequently, therapeutic strategies targeting SL1 should affect viral translation at early and late stages of infection. Therefore, SL1 might be seen as a genuine "Achilles heel" of the virus.
\end{abstract}

Keywords: SARS-CoV-2; NSP1; SL1; 5'UTR; translation; ribosome

\section{INTRODUCTION}

The SARS-CoV-2, of the beta-coronavirus family, recently emerged as responsible for the Covid-19 world pandemic (Andersen et al. 2020; Zhou et al. 2020). Its genome is a positive single strand RNA molecule containing 29,903 nt entirely sequenced at the end of 2019 (Chan et al. 2020; Lu et al. 2020). The viral genomic RNAs of coronaviruses are capped at their $5^{\prime}$ end and polyadenylated at their 3' end (Nakagawa et al. 2016; Hartenian et al. 2020). After entry into the infected cell, the viral genome from SARS-CoV-2 hijacks the host translation machinery in order to produce the viral proteins required for the viral infectious program and the production of novel viral particles (Hartenian et al. 2020). Like many viruses, SARS-CoV-2 orchestrates viral translation concomitantly with the specif-

Corresponding author: f.martin@ibmc-cnrs.unistra.fr

Article is online at http://www.rnajournal.org/cgi/doi/10.1261/rna. 078121.120. Freely available online through the RNA Open Access option. ic shutdown of cellular mRNA translation. The goal of this silencing is dual. First, general cellular translation inhibition generates the large pool of ribosomes necessary to ensure efficient and massive synthesis of viral proteins. Interestingly, the cellular mRNAs coding for protein components of the translational machinery, such as ribosomal proteins and translation factors, are preserved from the overall translation inhibition presumably in order to maintain a functional translational machinery during viral translation (Rao et al. 2020). Secondly, the cellular translation silencing inhibits more specifically mRNA subsets that are involved in cellular immune responses to viral infection.

In coronaviruses, viral translation begins with the expression from ORF1a that is translated into a polyprotein further processed by proteolytic cleavages to produce nonstructural proteins (NSP) involved in the multiple steps

C 2021 Tidu et al. This article, published in RNA, is available under a Creative Commons License (Attribution-NonCommercial 4.0 International), as described at http://creativecommons.org/licenses/ by-nc/4.0/. 
of the general viral infectious program (Masters 2006). The amino-terminal proximal protein NSP1 is one of the first viral proteins that is produced at the onset of the infectious program. NSP1 is required for efficient host cellular translation inhibition. For example, in SARS-CoV, NSP1 first recruits a yet unidentified cellular endonuclease that promotes specific mRNA degradation on translated mRNAs (Kamitani et al. 2006, 2009). These cleavages occur on the ribosome during translation elongation. Importantly, viral mRNA transcripts are resistant to NSP1mediated cleavages (Huang et al. 2011a). Secondly, the SARS-CoV NSP1 prevents translation initiation by interfering with the preinitiation complex formation at multiple steps (Lokugamage et al. 2012). The SARS-CoV NSP1 is thus directly responsible for general translation inhibition (Narayanan et al. 2008; Tohya et al. 2009; Huang et al. 2011 b). Similarly, the NSP1 protein from Mouse Hepatitis Virus (MHV), another member of the beta-coronavirus family, is also important for cellular translation inhibition (Lei et al. 2013). However, the impact of NSP1 on translation is stronger on specific mRNAs. Among the targets of NSP1, mRNA subsets involved in specific cellular immune responses are primarily shut off. Thus, NSP1 suppresses type I interferon responses during infection by SARS-CoV (Narayanan et al. 2008) and SARS-CoV-2 (Lei et al. 2020; Xia et al. 2020). The SARS-CoV-2 viral protein NSP1 binds to the host $40 S$ ribosomal subunit with high affinity and a $K_{d}$ in the nanomolar range (Lapointe et al. 2020). Actually, NSP1 proteins from SARS-CoV and SARS-CoV-2 are highly homologous. The amino-terminal domain of SARS-CoV was determined by NMR (Almeida et al. 2007). The carboxy-terminal domain of SARS-CoV-2 NSP1 contains an intrinsically disordered domain from residues 130 to 180 (Kumar et al. 2020). However, when bound to the ribosome, the SARS-CoV-2 NSP1 carboxyterminal domain is folded and binds tightly to the mRNA entry channel (Schubert et al. 2020; Thoms et al. 2020). NSP1 carboxy-terminal residues from 148 to 180 interact with ribosomal proteins uS3 and uS5 and with helix h18 from the 18S rRNA (Schubert et al. 2020; Thoms et al. 2020). Interestingly, the SARS-CoV-2 NSP1 binding site overlaps with the binding sites of the initiation factors elF1 and elF3j (Lapointe et al. 2020) and, thus, the binding of NSP1 to the $40 \mathrm{~S}$ prevents the formation of the $48 \mathrm{~S}$ preinitiation complex necessary for efficient translation (Brito Querido et al. 2020). Single molecule approaches have shown that SARS-CoV-2 NSP1 is competing with the mRNA in the mRNA channel (Lapointe et al. 2020).

Recently, it has been shown that the amino-terminal domain of SARS-CoV-2 NSP1 is required for viral translation by NSP1-bound ribosomes (Shi et al. 2020). The linker length between the amino- and carboxy-terminal domains is critical for viral translation (Shi et al. 2020). Beside the positive single strand genomic RNA, nine subgenomic RNAs (S, 3a, E, M, 6, 7a, 7b, 8, and N) are produced during the late phase of the infection by SARS-CoV-2 (Kim et al. 2020). Similar to other coronaviruses, all the viral transcripts are capped at their $5^{\prime}$ end with the first two nucleotides being ribose methylated and polyadenylated at their $3^{\prime}$ end (Yogo et al. 1977; Lai and Stohlman 1981). In the case of SARS-CoV-2, the median length of the polyA tail on viral transcripts is 47 A residues (Kim et al. 2020). In coronaviruses, all viral transcripts contain the common socalled $5^{\prime}$ leader sequence (nucleotides 1 to 75 ) that forms the hairpins SL1, SL2, and SL3 (Sola et al. 2015). This is also the case for SARS-CoV-2 (Kim et al. 2020; Miao et al. 2020).

Here we show that SARS-CoV-2 viral translation is evading NSP1-mediated inhibition because the viral transcripts, genomic and subgenomic RNAs, all contain a specific region of the leader sequence. More specifically, the sole hairpin SL1 is promoting NSP1 evasion by acting on the NSP1 carboxy-terminal domain in order to enable viral RNAs accommodation in the ribosome for their translation. The interaction between the SL1 RNA hairpin and the NSP1 carboxy-terminal domain occurs while NSP1 remains bound on the ribosome. Therefore, NSP1 acts as a ribosome gatekeeper to impair cellular translation and specifically promote viral translation.

\section{RESULTS}

\section{The evasion from NSP1 inhibition is due to cis-acting elements located in the SARS-CoV-2 5'UTR}

To measure the impact of the SARS-CoV-2 5'UTR on viral translation, we inserted in a reporter construct the 5'UTR upstream of the Renilla luciferase coding sequence. As a control, a similar reporter containing the EMCV IRES was used. Using rabbit reticulocyte lysates (RRL), we measured translation efficiency of Renilla luciferase in the absence and presence of increasing concentrations of recombinant SARS-CoV-2 NSP1 (Fig. 1). Translation efficiency of both constructs is reduced by NSP1. However, translation is significantly less affected with the SARS-CoV-2 5'UTR construct, indicating that the SARS-CoV-2 5'UTR allows evasion from NSP1-mediated inhibition. This is in good agreement with previous studies that showed that NSP1 is indeed inhibiting EMCV-driven translation but not SARS-CoV translation (Lokugamage et al. 2012). Moreover, since we are using $5^{\prime}$ labeled capped RNAs, the fact that we monitor the formation of radioactive translation complexes in the presence of NSP1 demonstrates that the SARS-CoV2 mRNA is not degraded. To investigate further the evasion of SARS-CoV-2 viral translation from NSP1 inhibition, we analyzed the formation of the ribosomal preinitiation complex by fractionation on sucrose gradients. The RNA transcripts were radiolabeled at their $5^{\prime}$ ends and incubated in RRL. We used a minimal RNA containing the whole SARS-CoV-2 5'UTR and the first 12 codons of the NSP1 coding sequence (nt 1-300) fused to a minimal portion of 


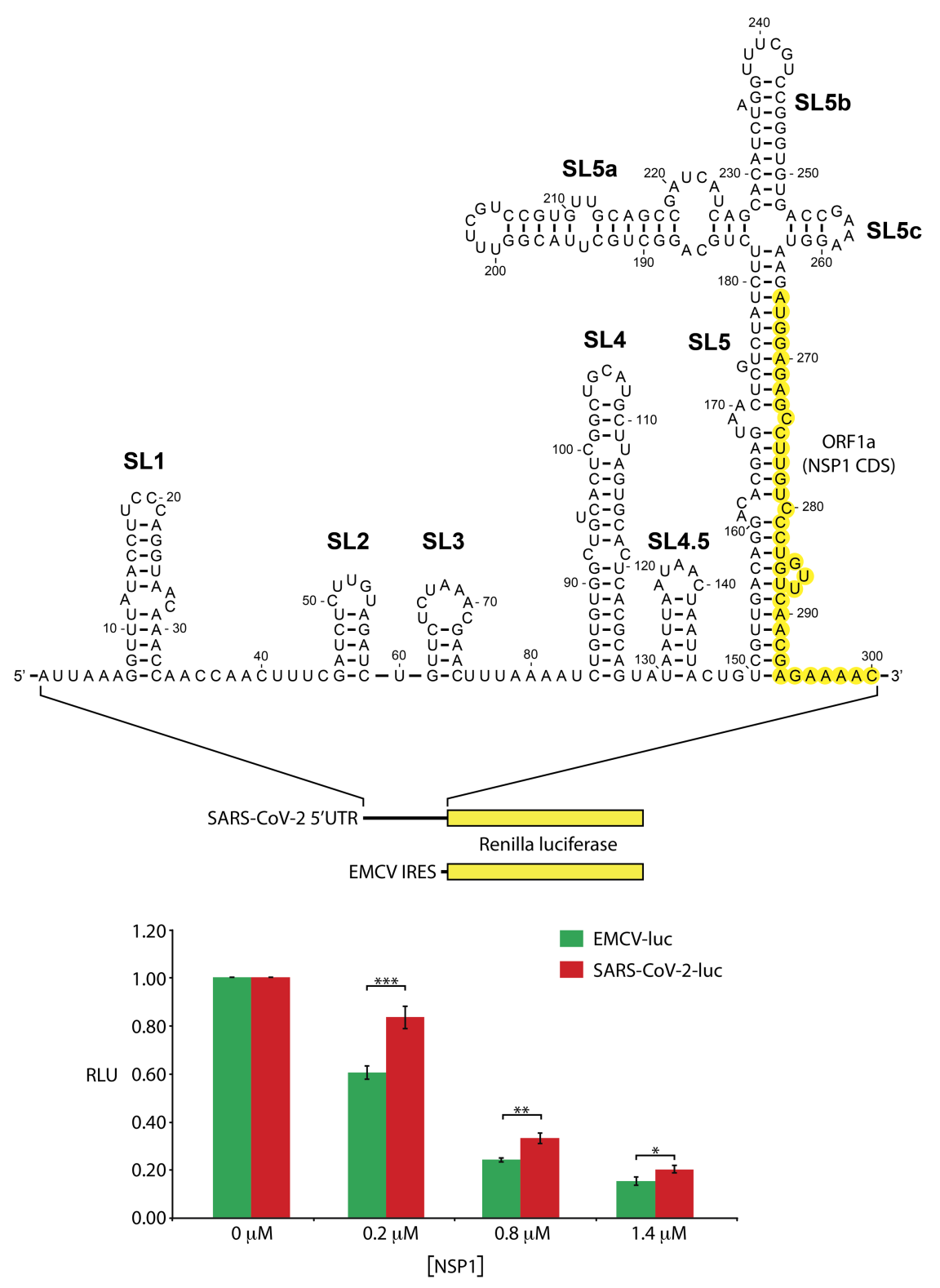

FIGURE 1. Translation inhibition by viral NSP1. The first reporter construct contains the SARSCoV2 5'UTR plus the $12 \mathrm{~N}$-terminal codons of NSP1 (nucleotides 1-300) fused to Renilla luciferase coding sequence. The second reporter contains the EMCV IRES upstream of the Renilla luciferase coding sequence. Translation efficiency was measured in the absence or presence of $0.2,0.8$, and $1.4 \mu \mathrm{M}$ of recombinant NSP1. Standard deviations or translational activity for each transcript are shown and calculated from eight independent experiments. $\left(^{*}\right) 0.05>P$-value $\left.>0.01 ;{ }^{* *}\right) 0.01>P$-value $>0.001 ;\left(^{* * *}\right) P$-value $<0.001$; based on Student's t-test.

ferent from the one driven by EMCV. However, in the presence of GMPPNP, a nonhydrolyzable GTP-analog that blocks the association of the large 605 ribosomal subunit (Gray and Hentze 1994), the accumulation of a $48 \mathrm{~S}$ complex is observed, as expected (Supplemental Fig. 1). In the presence of $0.8 \mu \mathrm{M} N S P 1$, the formation of these complexes is drastically reduced with the EMCV transcript. In contrast, the SARS-CoV-2 5'UTR transcript allows for the formation of 805 complexes to the same extent and with only a slight reduction of disomes. This experiment confirmed that the evasion from NSP1 inhibition is due to cis-acting elements located in the SARSCOV-2 5'UTR.

\section{The apical part of SL1 is absolutely required for NSP1 evasion}

In order to identify precisely the cisacting elements, we repeated the experiments with truncated SARSCoV-2 $5^{\prime}$ UTRs. With the $5^{\prime}$ proximal $40 \mathrm{nt}$ deleted $(\Delta 40)$, the protection toward NSP1-mediated inhibition is totally abrogated, which indicates that this part of the $5^{\prime}$ UTR contains essential cis-acting elements (Fig. 2B; Supplemental Fig. 2). This region of the $5^{\prime}$ UTR contains the predicted hairpin SL1 (Rangan et al. 2020) that was confirmed by probing experiments (Miao et al. 2020). Next, we introduced four mutations in the upper part of SL1. These mutations prevent the formation of the apical stem-loop of SL1 (called SL1 mut) (Fig. 2C). We have verified that the introduced mutations do induce the opening of SL1 (Supplemental Fig. 3). Again, the formation of preinitiation complexes is totally prevented with SL1 mut, indi-

the luciferase coding sequence (Fig. 2). The formed preinitiation complexes are then fractionated on sucrose gradient and collected in separate fractions. The presence of the radioactive RNAs in the collected fractions was then monitored by Cerenkov counting. With this experimental set-up, we detected the formation of 48S, 80S, and disomes for EMCV and SARS-CoV-2 constructs (Fig. 2A). With SARS-CoV-2, the $48 \mathrm{~S}$ complex is almost absent indicating that the initiation process in this $5^{\prime}$ UTR might be dif- cating that evasion to NSP1-mediated inhibition is abrogated. Thus, the apical part of SL1 is absolutely required for NSP1 evasion.

\section{A fully functional NSP1 is necessary for translation inhibition}

Mutations of residues K164 and H165 of NSP1 into alanines totally abolish the binding to the $40 \mathrm{~S}$ subunit 
Tidu et al.

A

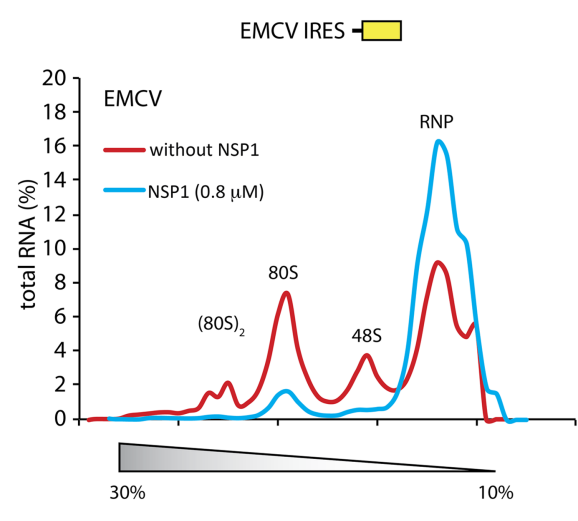

B

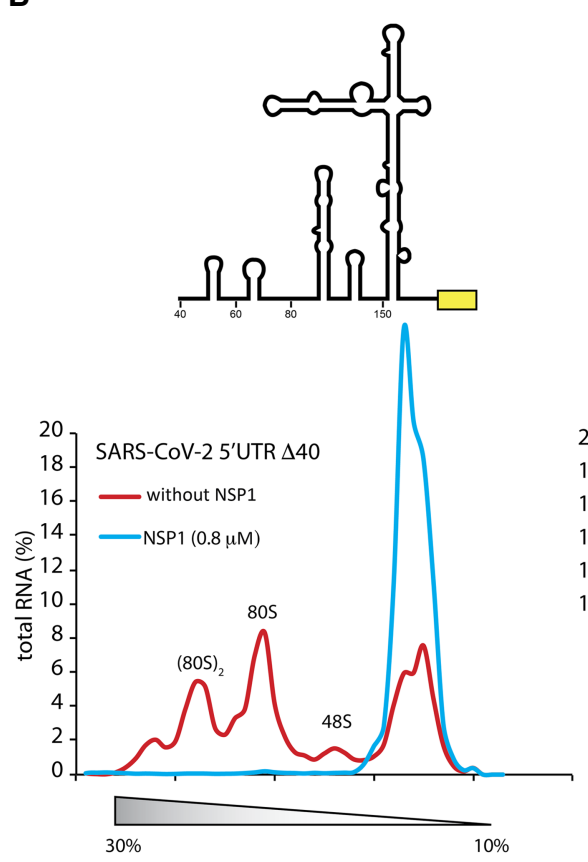

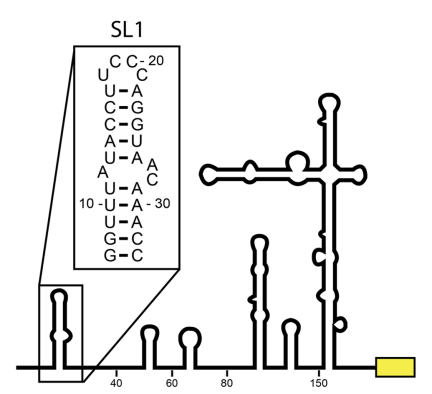

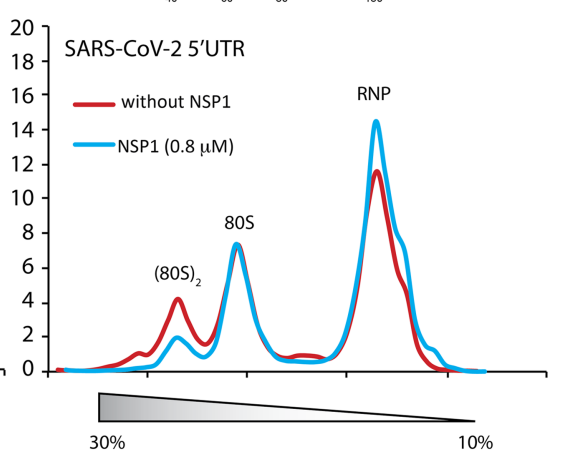

C

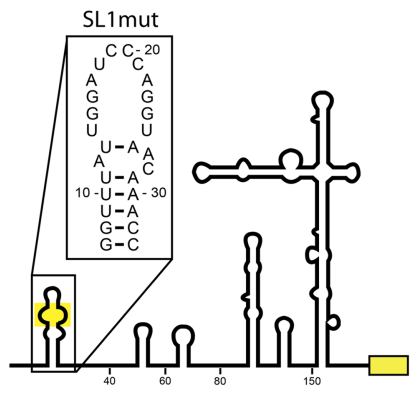

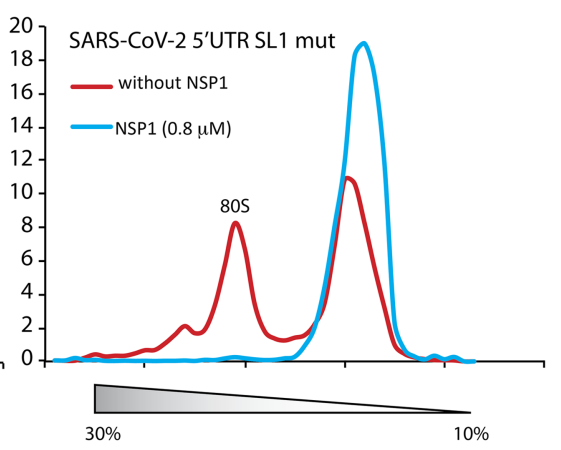

FIGURE 2. SL1 is required in the SARS-CoV-2 5'UTR for NSP1 evasion. Preinitiation complex formation analysis on 10\%-30\% sucrose gradients using radiolabeled RNA at their $5^{\prime}$ end. The SARS-CoV-2 RNA transcript was radiolabeled with a radioactive $m 7 \mathrm{G}$ cap at its $5^{\prime}$ end. The preinitiation complexes were fractionated on $10 \%-30 \%$ sucrose gradients. The presence of radioactive RNA was monitored by Cerenkov counting of all the fractions. The plots represent the percentage of radioactive RNA that was used for complex formation. The preinitiation complexes were formed in the absence (red line) or presence of $0.8 \mu \mathrm{M}$ of recombinant viral NSP1 (blue line). The positions of ribonucleoproteins (RNP), the 48S, 80S, and disomes are indicated above the curves. (A) Translation initiation complexes analysis on sucrose gradients with EMCV reporter mRNA (left panel) and with SARS-CoV-2 reporter mRNA (right panel). Translation initiation complexes analysis on sucrose gradients with a truncated SARS-CoV-2 (B) or a SARS-CoV-2 5'UTR containing a mutation that disrupts SL1 (C).

(Kamitani et al. 2009). Likewise, the mutations R124A and K125A inhibit NSP1 ability to promote translation inhibition (Lokugamage et al. 2012). We tested the effect of these mutations in SARS-CoV-2 NSP1 on the preinitiation complex formation with the SARSCoV-2 containing a mutated SL1. As expected, the wild-type NSP1 severely reduces the formation of the preinitiation complexes when SL1 is mutated. In contrast, none of the two NSP1 mutants affects the translation, indicating that NSP1 has to be bound to the ribosome to inhibit translation efficiently (Supplemental Fig. 4). Altogether, these experiments demonstrate that the presence of the cis-acting element SL1 and a NSP1 protein able to bind ribosomes is necessary to promote a viral translation resistant to NSP1-mediated inhibition.

\section{The apical part of the SL1 RNA hairpin is solely responsible for NSP1 resistance}

Next, we tested if $S L 1$ is solely responsible for NSP1-resistance. For that purpose, we measured the impact of NSP1 on translation of another reporter construct containing the $\beta$-globin 5'UTR upstream of the Renilla coding sequence. Translation is significantly inhibited in the presence of increasing concentrations of NSP1, confirming the general inhibitory effect of NSP1 bound on the ribosome (Fig. 3A). We then transplanted the $5^{\prime}$ proximal 40 nt of the SARS-CoV-2 $5^{\prime}$ UTR, which contain the SL1 hairpin, upstream of the $\beta$-globin $5^{\prime} U T R$. The sole presence of SL1 allowed a significant protection against NSP1 inhibition. In contrast, when SL1 mut is transplanted, no protection is observed. Since the subgenomic RNAs contain the so-called leader sequence that encompasses SL1, SL2, and SL2 in their $5^{\prime}$ UTR, we checked whether SL2 and SL3 are also required for NSP1 evasion. Indeed, addition of SL2 and SL3 only slightly improves the translation efficiency in the presence of NSP1 (Fig. 3B). This experiment indicates that 
A
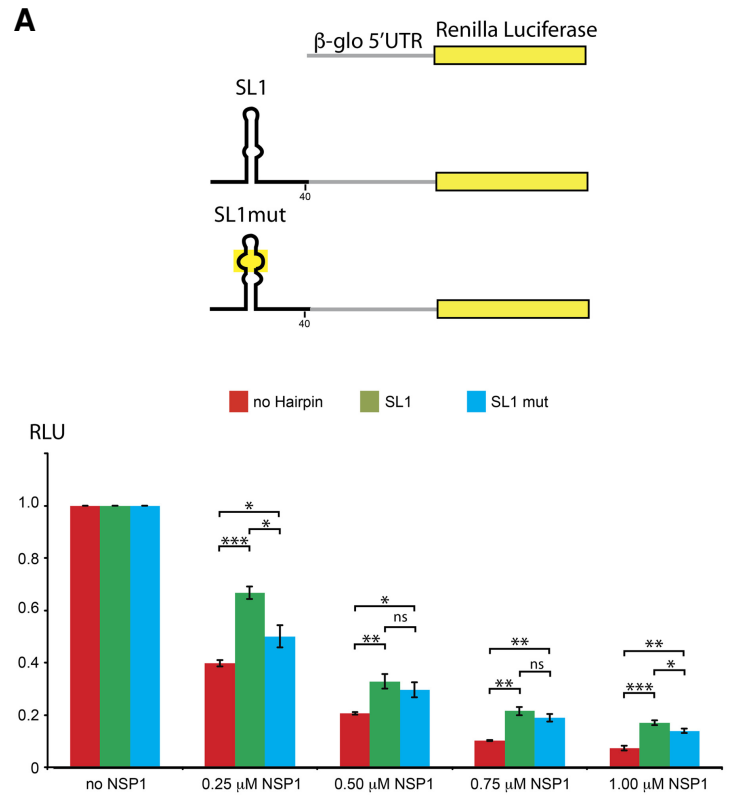

B
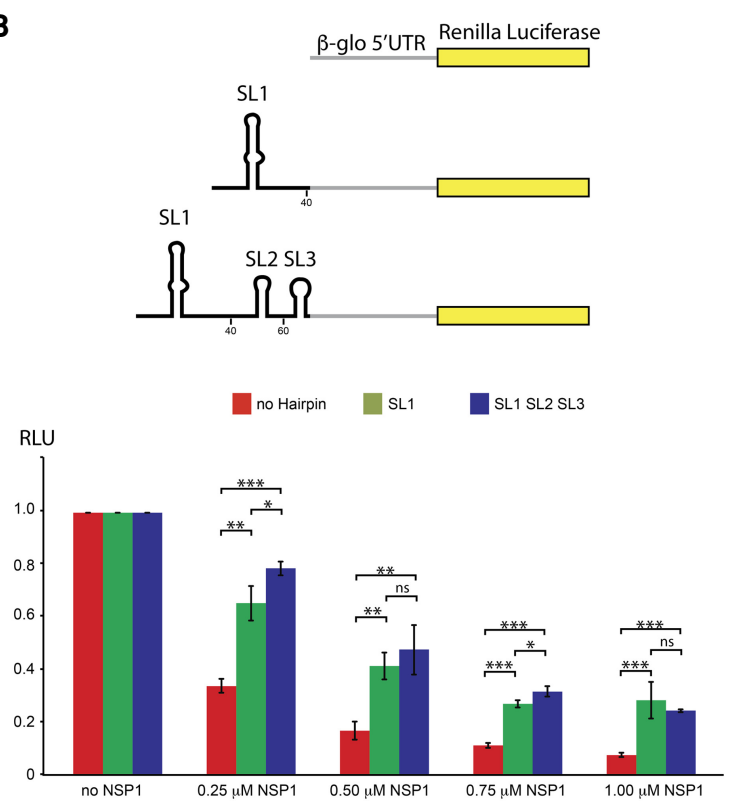

FIGURE 3. SL1 is sufficient to confer resistance to NSP1 inhibition. (A) Luciferase reporter mRNAs containing $\beta$-globin $5^{\prime} U T R$, SL1- $\beta$-globin $5^{\prime} U T R$, and SL1mut- $\beta$-globin $5^{\prime}$ UTR were used to measure their translation efficiency in RRL in the absence or presence of $0.25,0.50,0.75$, and $1 \mu \mathrm{M}$ of recombinant NSP1. The average relative activities from three independent experiments are represented in the histogram. The activity of the reporter $\beta$-globin 5'UTR luciferase in the absence of NSP1 is used as a control for normalization. (B) Luciferase reporters containing $\beta$-globin 5'UTR or with SL1, or with SL1-SL2-SL3 in their 5'UTR. Standard deviations or translational activity for each transcript are shown and calculated from three independent experiments. (ns) nonsignificant; $\left(^{*}\right) 0.05>P$-value $>0.01 ;\left(^{* *}\right) 0.01>P$-value $>0.001 ;\left(*^{* *}\right) P$-value $<0.001$; based on Student's t-test.

subgenomic RNAs can also evade to NSP1-mediated inhibition because they harbor SL1 in their 5'UTR. These data confirm that the apical part of SL1 is essential for NSP1 evasion. Altogether, these results indicate that the evasion of the SARS-CoV-2 RNAs to NSP1 inhibition is due solely to the presence of SL1 in the 5'UTR leader sequence.

\section{Free NSP1 has no affinity for RNA}

A putative mechanism would be that SL1 directly interacts with NSP1 and thereby removes NSP1 from the ribosome to allow access to the mRNA channel of the ribosome during the initiation process of mRNA accommodation. To evaluate such a mechanism, we tested the RNA binding ability of NSP1 (Fig. 4A). We used radiolabeled RNAs from SARS-CoV-5'UTR with EMVC and HCV IRES as negative controls. None of the RNAs tested are bound by NSP1 even when $20 \mu \mathrm{M}$ of NSP1 was used for Electrophoretic Mobility Shift Assay (EMSA). We concluded from these experiments that free NSP1 has no affinity for RNA even when it contains SL1 like the SARS-CoV-2 5'UTR.

\section{The SARS-CoV-2 5'UTR does not bind to any component of the ribosome on its own}

However, NSP1 has a strong affinity for the $40 \mathrm{~S}$ ribosomal subunit, and its carboxy-terminal domain binds into the
mRNA channel with a $K_{d}$ in the nanomolar range (Lapointe et al. 2020). We therefore tested whether a SARS-CoV-2 transcript is able to bind to pure ribosomal subunits by EMSA. To validate our assay, we used the HCV IRES as a positive control, since it was shown earlier that it interacts specifically with the $40 \mathrm{~S}$ ribosomal subunit (Filbin et al. 2013; Fuchs et al. 2015; Quade et al. 2015; Yamamoto et al. 2015) and even with full 80 S (Yokoyama et al. 2019). As expected, the HCV IRES interacts with purified human 405 ribosomal subunit and with the 405 subunit from the complete $80 \mathrm{~S}$ ribosome. In contrast to the HCV IRES, the SARS-CoV-2 5'UTR is not able to bind the 40S, and neither to the 60S nor the 805 particles (Fig. $4 B$ ). In summary, NSP1 has a strong affinity for the ribosomal 40 S subunit but the SARS-CoV-2 5'UTR cannot bind to any component of the ribosome on its own.

\section{The SARS-CoV-2 5'UTR promotes the assembly of preinitiation complexes in the presence of NSP1: the interaction between NSP1 and SL1 frees the mRNA accommodation channel while maintaining NSP1 bound to the ribosome}

However, our results also indicate that the SARS-CoV-2 5'UTR promotes the assembly of preinitiation complexes in the presence of NSP1. First, we carefully checked that all the ribosomal complexes that are assembled on the SARS-CoV-2 5'UTR are fully functional and do not 
A
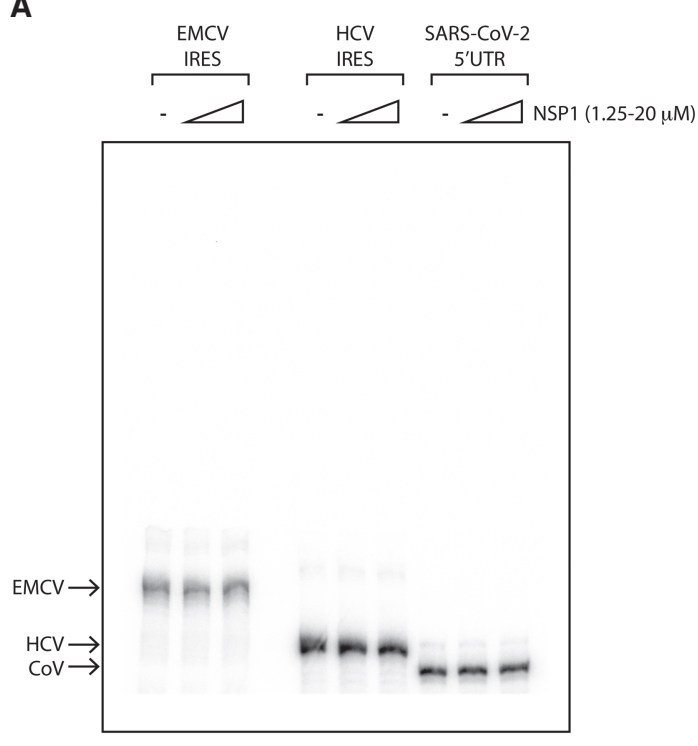

B

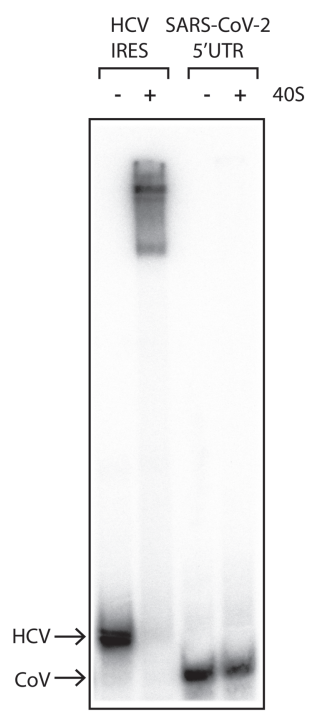

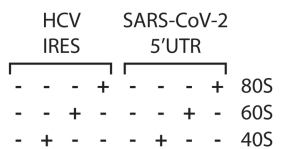

$-+-\cdot+--405$

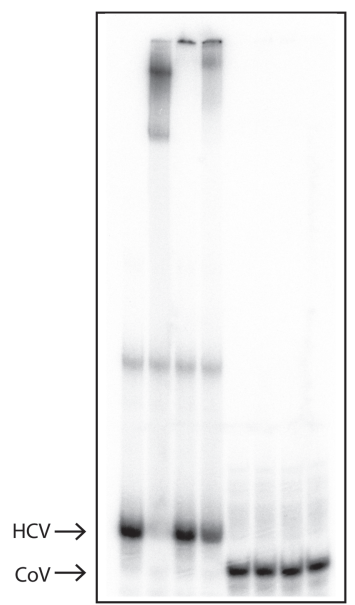

FIGURE 4. NSP1 has no RNA binding ability on its own. (A) Electrophoretic mobility shift assay using radiolabeled RNA containing EMCV IRES, HCV IRES, and the SARS-CoV-2 5'UTR. The RNAs were incubated in the presence of 1.25 to $20 \mu \mathrm{M}$ recombinant NSP1 and loaded on native polyacrylamide gel. (B) The SARS-CoV-2 5'UTR was also used to test its binding to ribosomal 40S (left panel) and to 40S, 60S, and 80S (right panel). The HCV IRES was used as a positive control. The positions of the free RNA are indicated by arrows.

correspond to nonproductive ribosome complexes. Indeed, in the presence of GMP-PNP, we see efficient accumulation of $48 \mathrm{~S}$ particles. In contrast, in the presence of edeine, which interferes specifically in the P-site with the codon-anticodon interaction between the initiator tRNA and the start codon, no 805 ribosomal complexes are assembled and only $43 \mathrm{~S}$ complexes, presumably scanning complexes, are observed (Supplemental Fig. 1). These experiments demonstrate that the ribosome complexes that are assembled on SARS-CoV-2 5'UTR are fully functional and that nonproductive complexes are absent. In order to determine whether NSP1 is removed from the assembled preinitiation complexes, we used a previously established protocol that yields purified preinitiation complexes programmed with SARS-CoV-2 5'UTR (Prongidi-Fix et al. 2013; Chicher et al. 2015; Martin et al. 2016). The principle is to use a chimeric molecule composed on one hand by the RNA region encompassing the SARS-CoV-2 5'UTR followed by a small coding sequence and a DNA oligonucleotide coupled to Biotin at its $3^{\prime}$ end (Fig. 5A). The hybrid molecules are then immobilized on magnetic streptavidin beads and incubated in RRL in the presence of cycloheximide. Cycloheximide blocks the first translocation step and, therefore, incubation of SARS-CoV-2 5'UTR in RRL, previously treated with cycloheximide, leads to the accumulation of 805 ribosomes that are stalled on the start codon. The complexes are then eluted by DNase digestion that removes the Biotin and the DNA linker. The composition of the eluted ribosomal complexes is determined by mass spectrometry analysis. We performed in parallel two experiments with the SARS-CoV-2 5'UTR in the presence or in the absence of NSP1. Each experiment was repeated three times (Fig. 5B). Since cycloheximide induces the stalling of 805 complexes on the start codon, the $5^{\prime}$ cap of the mRNA is still accessible. Therefore, another scanning complex can also be present on the mRNA, meaning that we can in fact purify $43 \mathrm{~S}, 48 \mathrm{~S}$, and $80 \mathrm{~S}$ complexes at the same time. Concerning elongation, it is well described that cycloheximide does not allow a $100 \%$-blockage and that a small proportion of disomes is always observed, which explains the presence of elongation factors in our complexes. The important point here is that NSP1 is still present together with disomes, 805 and scanning complexes. Since all these complexes are assembled with the mRNA in the mRNA channel, we have to conclude on the presence of NSP1 on these ribosomal complexes but with its carboxy-terminal domain displaced from the mRNA channel to enable the presence of mRNA.

Two actin-binding proteins, MYH9 and MYH10, are depleted from the complexes when NSP1 is present. Interestingly, it has been reported that depletion or inactivation of the myosin nonmuscle proteins $\mathrm{MYH9}$ and MYH10 leads to renal failure (Otterpohl et al. 2020) or pulmonary disease (Kim et al. 2018), characteristic symptoms of SARS-CoV-2 infection.

In these two experiments, preinitiation complexes were efficiently purified as attested by the presence of $40 \mathrm{~S}$ and 605 ribosomal proteins and eukaryotic initiation factors (elFs) (Fig. 5C). In both complexes, we found the full set of ribosomal proteins from the 605 and the 405 ribosomal 
A

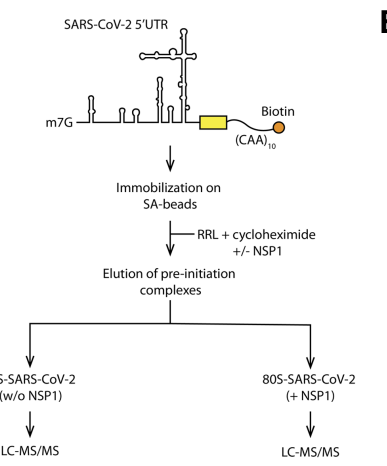

B
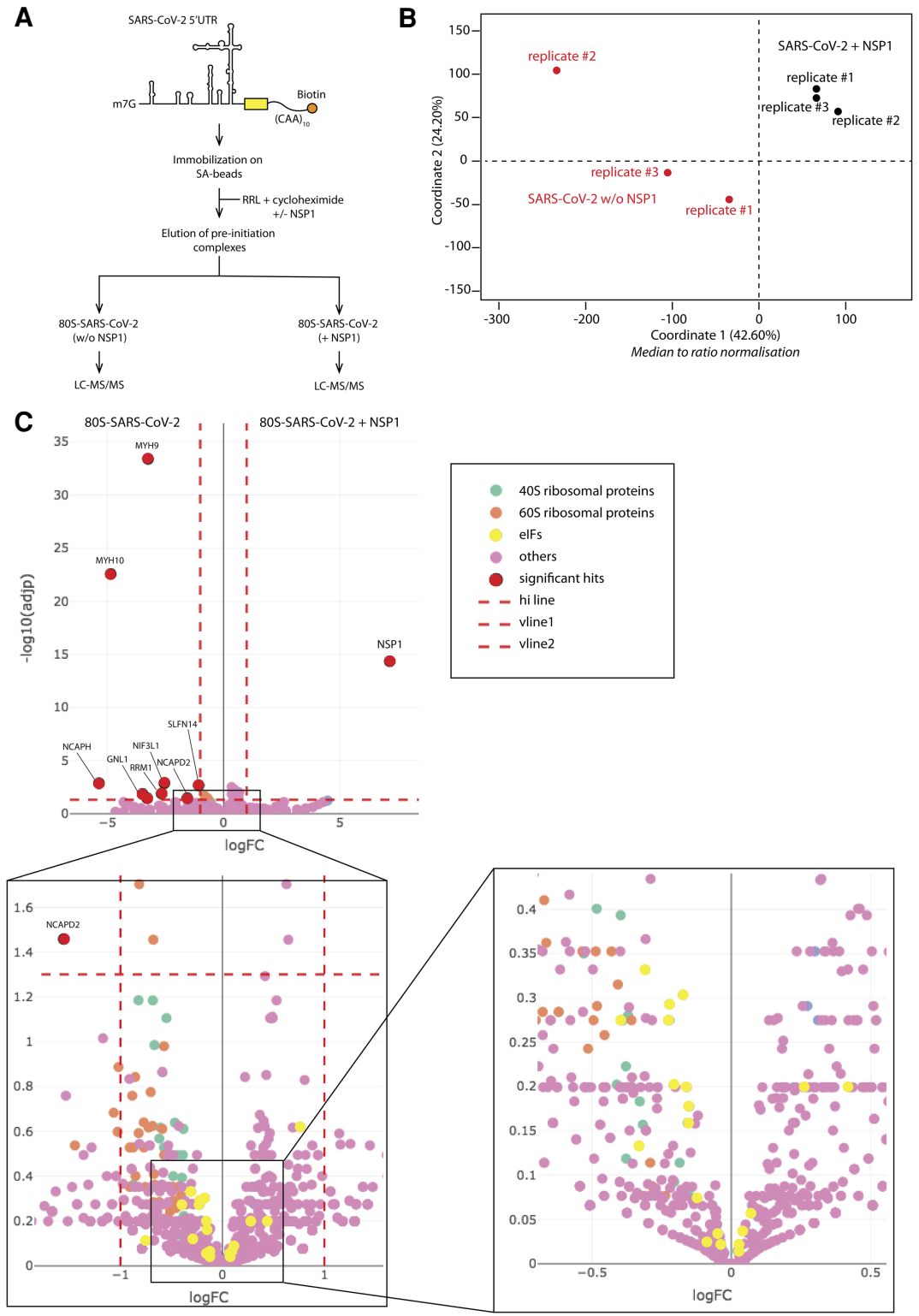

FIGURE 5. NSP1 remains bound to the preinitiation complex programmed with SARS-CoV-2 $5^{\prime}$ UTR. (A) Experimental strategy adapted from Chicher et al. (2015) to purify translation initiation complexes programmed with SARS-CoV-2 5'UTR in the absence or presence of recombinant NSP1. (B) Multidimensional scaling plot illustrating global variance and similarities between the SARS-CoV-2 (w/oNSP1) and SARS-CoV-2 (+NSP1) populations detected in the replicates, after a median-to-ratio normalization. (C) Volcano plot showing the proteins copurified with NSP1 as compared to the control condition performed without NSP1. Y-and $x$-axes display adjusted $P$-values and fold changes, respectively. The proteins indicated by a red circle are enriched in either the SARS-CoV-2 (+NSP1) condition ( $\left.\log _{2} \mathrm{FC}>1\right)$ or in the SARS-CoV-2 (w/oNSP1) condition (Log2FC $<-1$ ). The dashed line indicates the threshold above which proteins are significantly enriched (adj $P<0.05)$. Magnifications of the nonsignificant hits are shown in order to visualize better the proteins from the translation machinery. Green and orange circles label the $40 \mathrm{~S}$ and $60 \mathrm{~S}$ ribosomal proteins, respectively, yellow circles label the initiation factors, and purple circles correspond to other proteins. The source data are available in Supplemental Table 1.

subunits (50 proteins and 36 proteins, respectively) (Supplemental Table 1). The fact that proteins from the translation machinery were found in both complexes con- firms that NSP1 does not inhibit translation of SARS-CoV-2 mRNAs. Importantly, we found that NSP1 is still present in the preinitiation complexes formed in the presence of NSP1. This indicates that the purified preinitiation complexes contain NSP1 still bound on the ribosome. Thus, these experiments imply that the mRNA channel is accessible to the mRNA and that the NSP1 carboxy-terminal domain must have been remodeled in order to allow mRNA accommodation. Since NSP1 is present in these preinitiation complexes, this suggests that NSP1 remains attached to the ribosomal subunit with its amino-terminal domain (according to data from Shi et al. 2020). The addition of purified transcripts containing SL1 or SL1SL2-SL3 in trans (with a 10-fold excess) does not rescue the translation in the presence of NSP1 (data not shown). Therefore NSP1-evasion does require the presence of SL1 in cis on the mRNA.

\section{DISCUSSION}

Altogether, our data enable us to propose the following model (Fig. 6). During the early stages of the SARSCoV-2 infectious program, ORF1a is translated by canonical cap-dependent translation. The corresponding protein is then processed into NSP proteins. Among these, NSP1 binds to the ribosome with a high affinity. Its carboxy-terminal domain interacts with the mRNA channel entry site and thereby blocks the access to mRNAs. Cellular translation is consequently drastically shut down. However, viral translation escapes this blockage and still goes on. We have confirmed that viral translation is proceeding further in the presence of NSP1 in a so-called viral evasion. We demonstrated here that SL1 is required for this viral evasion. Deletion of SL1 abrogates NSP1 evasion which is in good agreement with a previously published model in which viral translation is also inhibited by NSP1 (Schubert et al. 2020). Indeed, according to the primers described in this publication, the reporter 


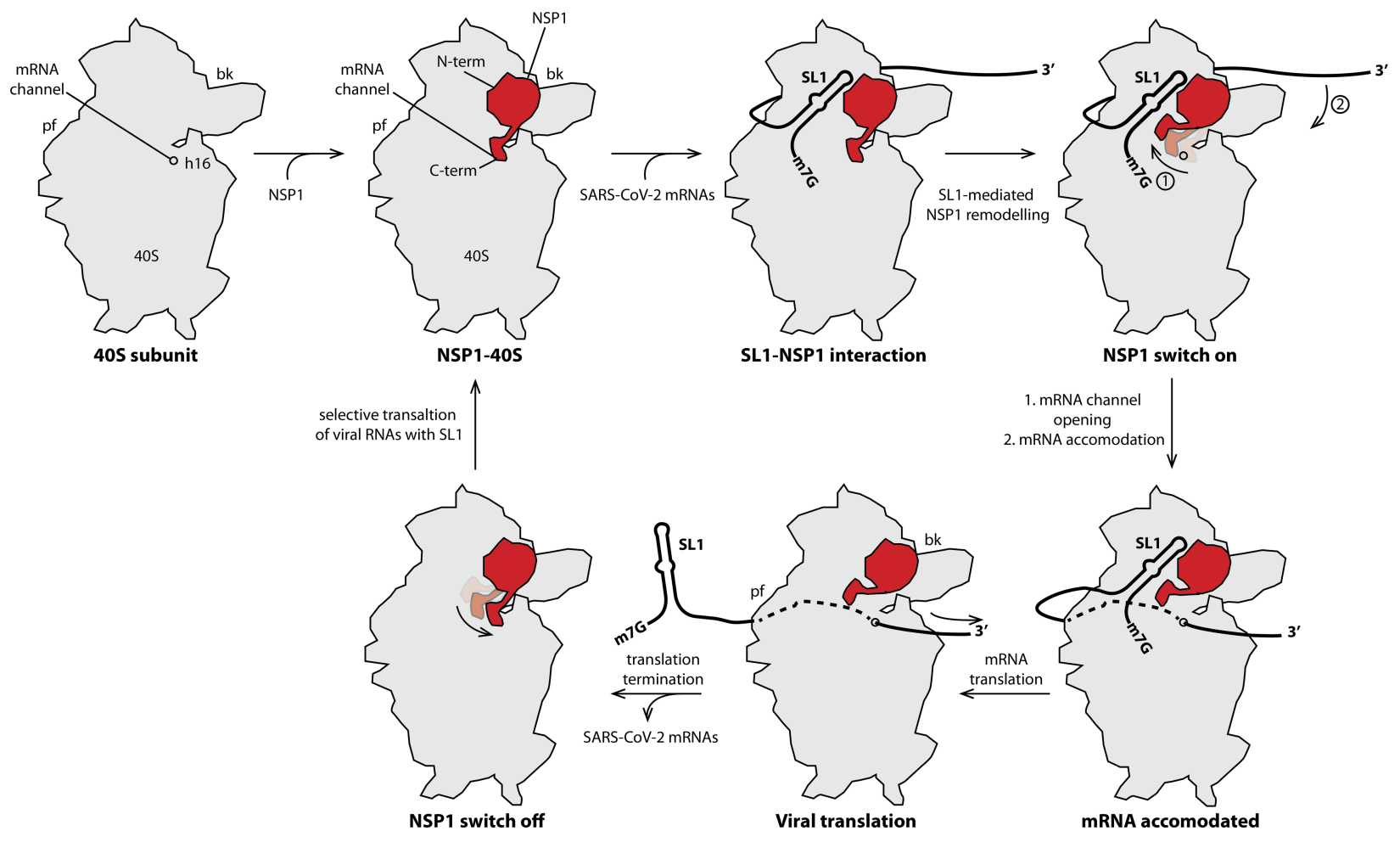

FIGURE 6. Model for NSP1 acting as a gatekeeper to ensure NSP1 evasion by SARS-CoV-2 $5^{\prime} U T R$. In the early phase of infection, NSP1 protein is produced and binds with high affinity to the $40 \mathrm{~S}$ ribosomal subunit. The images of the 40S subunits are shown from the solvent side. NSP1 binds on the beak of the $40 \mathrm{~S}$ by interacting with the amino-terminal part of NSP1; this interaction places the carboxy-terminal part of NSP1 in the mRNA channel entry site and thereby prevents any mRNA accommodation. The viral mRNA transcripts contain in their $5^{\prime}$ UTR SL1, that by interacting with the 40S-NSP1 complex enables mRNA accommodation and the formation of translation initiation complexes (the mRNA is accommodated in the decoding site on the 4OS intersubunit side and is shown with dashed line). This required the removal of the carboxy-terminal domain of NSP1 to open access to the mRNA channel. Then, translation initiation, elongation, and termination can proceed further. After termination, the mRNA is released, the NSP1 carboxy-terminal can refold in front of the mRNA channel and prevent any de novo cellular mRNA translation. Only viral mRNA transcripts can access the mRNA channel, thanks to the SL1 that is present in the 5'UTR of genomic and subgenomic RNAs.

used in the later study did not contain SL1, which in fact confirms our results obtained with $\Delta 40, \Delta 60, \Delta 80$, and $\Delta 150$ (Supplemental Fig. 2) that showed that viral evasion is abrogated when SL1 is deleted.

In the model deduced from the available and the present data (Fig. 6), the SARS-CoV-2 5'UTR contains a cis-acting element, the SL1 hairpin, that induces during translation initiation a structural rearrangement of NSP1, especially of its carboxy-terminal domain. This frees the access to the mRNA channel and allows viral translation to proceed further. This model is in good agreement with two models recently proposed by others (Banerjee et al. 2020; Shi et al. 2020). They found that the amino-terminal part of NSP1 is required for evasion from NSP1 inhibition, that the length of the linker between the amino- and carboxy-terminal domains is critical and that the $5^{\prime}$ UTR is required for viral evasion. In addition, they proposed that NSP1 is removed from the ribosome and retained by an interaction between the amino-terminal domain of NSP1 and the 5'UTR (Banerjee et al. 2020; Shi et al. 2020). Although we cannot rule out this possibility, the fact that we have not been able to detect any RNA binding ability with free NSP1 is a strong argument against this suggestion. Moreover, if NSP1 is released from the ribosome, this will lead to free ribosomes that can start again to translate cellular mRNAs. To ensure efficient shut down of host translation, it is more efficient for the virus to maintain NSP1 on the ribosome. Therefore, we rather suggest that NSP1 stays bound on the ribosome. Within this model, at the end of translation, the carboxy-terminal domain of NSP1 folds back into the mRNA channel and prevents any de novo cellular translation. In the late phase of infection, nine subgenomic RNAs are produced. Interestingly, all these viral transcripts contain the so-called leader body junction that contains SL1, SL2, and SL3 (Kim et al. 2020). The presence of SL1 in all the SARS-CoV-2 transcripts probably ensures efficient NSP1 evasion while still allowing efficient translation. This is especially important for the translation of subgenomic RNAs that is required in the late phases of the infectious process when the concentration of NSP1 is high and when most if not all the ribosomes are blocked by NSP1. In the model presented 
in Figure 6, NSP1 acts as a gatekeeper to control selectively the access to the mRNA channel, preventing cellular translation and restricting translation to the sole viral transcripts. The release of the NSP1 gatekeeper is controlled by SL1 from viral transcripts. In conclusion, the sole presence of SL1 in all the SARS-CoV-2 transcripts is a prerequisite to complete the viral infectious program. Therefore, targeting SL1 for therapeutic purposes would be an elegant approach to impair viral translation, in the early phase but also in the late phases of SARS-CoV-2 infection.

Targeting NSP1 proteins from coronaviruses for the development of novel therapeutic strategies has been proposed earlier (Kamitani et al. 2006, 2009; Wathelet et al. 2007; Züst et al. 2007; Narayanan et al. 2008; Tohya et al. 2009; Huang et al. 2011a; Lokugamage et al. 2012; Tanaka et al. 2012; Jauregui et al. 2013; JimenezGuardeño et al. 2015; Wu et al. 2020). Another attractive alternative would be to target SL1. Indeed, SL1 being present in all the viral transcripts, drug-design against SL1 would allow to target specifically viral translation in the early phase of infection by impairing genomic RNA translation and in the late phase of infection by blocking translation of subgenomic RNAs. Altogether, SL1 might be seen as a genuine "Achilles heel" of SARS-CoV-2.

\section{MATERIALS AND METHODS}

\section{In vitro transcription}

The different variants of reporter constructs were transcribed by run-off in vitro transcription with T7 RNA polymerase. Uncapped RNAs were separated on denaturing PAGE (4\%) and RNA were recovered from the gel slices by electroelution. The resulting pure RNA transcripts were capped at their $5^{\prime}$ end with the ScriptCap m7G Capping System (Epicenter Biotechnologies).

\section{In vitro translation}

In vitro translation with cell-free translation extracts were performed using self-made rabbit reticulocyte lysates (RRL) as previously described (Martin et al. 2011). Briefly, reactions were incubated at $30^{\circ} \mathrm{C}$ for $60 \mathrm{~min}$ and included $200 \mathrm{nM}$ of each transcript and $10.8 \mu \mathrm{Ci}\left[{ }^{35} \mathrm{~S}\right] \mathrm{Met}$. Aliquots of translation reactions were analyzed for Renilla luciferase activity on a luminometer.

\section{Sucrose gradient analysis}

For sucrose-gradient analysis, $5^{\prime}-{ }^{32} \mathrm{P}$-labeled mRNA were incubated in self-made RRL, in the presence of recombinant NSP1. NSP1 was incubated with RRL 5 min at $30^{\circ} \mathrm{C}$ prior to addition of radiolabeled mRNAs. The translation initiation complexes were separated on a 10\%-30\% linear sucrose gradient in buffer $(25 \mathrm{mM}$ Tris- $\mathrm{HCl}$ [pH 7.4], $50 \mathrm{mM} \mathrm{KCl}, 5 \mathrm{mM} \mathrm{MgCl} 2,1 \mathrm{mM}$ DTT). The reactions were loaded on the gradients and spun $(23,411 \mathrm{~g}$ for $2.5 \mathrm{~h}$ at $4^{\circ} \mathrm{C}$ ) in a SW41 rotor. mRNA sedimentation on sucrose gradients was monitored by Cerenkov counting after fractionation.

\section{DNA templates and primers used}

A DNA fragment containing the 900 first nucleotides of SARSCOV-2 (accession number: MN908947.3) was ordered from Integrated DNA Technologies (IDT). The fragment was used as template for all the subsequent PCR amplifications. The DNA fragment corresponding to NSP1 (179 amino acid first NSP1 residues after TEV cleavage) was cloned in PET-His-GST-TEV-LIC(2GT) (Addgene) with Gibson Assembly Cloning Technology (Gibson et al. 2009). The plasmids containing the EMCV IRES and the $\beta$-globin sequence have been kindly provided by G. Goodall and by B. Sargueil, respectively. The primers used in this work are listed in Supplemental Table 2.

\section{Mass spectrometry analysis and data processing}

Proteins were digested with sequencing-grade trypsin (Promega) and analyzed by nano LCMS/MS as previously described (Chicher et al. 2015). Digested proteins were then analyzed on a QExactive + mass spectrometer coupled to an EASY-nanoLC-1000 (Thermo Fisher Scientific). MS data were searched against the Rabbit UniProtKB subdatabase (release 2020_05, taxon 9986, 43454 sequences) with a decoy strategy. Peptides were identified with Mascot algorithm (version 2.5, Matrix Science) and data were imported into Proline 1.4 software (Bouyssié et al. 2020). Proteins were validated on Mascot pretty rank equal to 1, Mascot score above 25 and 1\% FDR on both peptide spectrum matches (PSM score) and protein sets (Protein Set score). The total number of MS/MS fragmentation spectra was used to quantify each protein in each condition performed in three replicates. The statistical analysis based on spectral counts was performed using a homemade $R$ package that calculates fold change and $P$-values using the quasi-likelihood negative binomial generalized log-linear model implemented in the edgeR package (https://github.com/ hzuber67/IPinquiry4). The size factors used to scale samples were calculated according to the DESeq2 normalization method (i.e., median of ratios method). Volcano plots display the adjusted $P$-values and fold changes in the $y$ - and $x$-axis, respectively, and show the enrichment of proteins in both conditions. $P$-values were adjusted using Benjamini-Hochberg method from stats $\mathrm{R}$ package.

\section{NSP1 overexpression and purification}

NSP1 and derivatives (R124A+K125A-Inhibits translation, no mRNA degradation-(Lokugamage et al. 2012); K164A + H165A-biologically inactive-(Narayanan et al. 2008) were cloned in plasmid pET-His-GST-TEV-LIC-(2GT). The plasmid pET-His-GST-TEV-LIC-(2GT) was purchased from Addgene. This vector overexpresses fusion proteins carrying a 6-His-tag on the amino-terminal GST domain followed by TEV protease cleavable site and by the NSP1 native protein or mutants. The fusion proteins were expressed in E. coli BL21 Rosetta (DE3) pLysS cells. Cells were grown at $37^{\circ} \mathrm{C}$ to a cell density of $\mathrm{OD}_{600}=0.6$. Temperature was decreased to $20^{\circ} \mathrm{C}$ and cells were induced by addition of $0.1 \mathrm{mM}$ IPTG. Twelve hours after induction, pelleted cells were resuspended in EQ/W buffer ( $40 \mathrm{mM}$ Na phosphate $\mathrm{pH} 7.2,500 \mathrm{mM} \mathrm{NaCl}, 30 \mathrm{mM}$ imidazole) supplemented with $0.1 \%$ Triton X-100, cOmplete Protease Inhibitor Cocktail 
(Merck) and incubated on ice for $30 \mathrm{~min}$ with $1 \mathrm{mg} / \mathrm{mL}$ lysozyme. After lysis by sonification, the cell lysate was centrifuged at $105,000 \mathrm{~g}$ for $1 \mathrm{~h} 30 \mathrm{~min}$ and the supernatant was applied to $\mathrm{Ni}-$ NTA Superflow resin (QIAGEN) equilibrated in buffer EQ/W. After column washing, NSP1 proteins were eluted from the resin by buffer EQ/W containing $250 \mathrm{mM}$ imidazole. The NSP1 fraction was dialyzed against buffer EQ/W without imidazole overnight. The NSP1 fraction was loaded on Glutathione HiCap resin (Qiagen) equilibrated with the dialysis buffer and proteins were eluted by the same buffer supplemented with $50 \mathrm{mM}$ glutathione. The purified 6-His-GST-TEV-NSP1 fusion proteins were subjected to TEV protease cleavage overnight at $4{ }^{\circ} \mathrm{C}$ (50/1 fusion/ TEV molar ratios). NSP1 proteins were separated from the 6-HisGST domain using a last purification step on the Ni-NTA resin that retained His-tagged GST and TEV proteins. The pure NSP1 proteins were concentrated, and stored in buffer that contains $50 \%$ glycerol at $-20^{\circ} \mathrm{C}$.

\section{Ribosome purification}

Ribosomes from HeLa cells were purified according to the previous protocol established for rabbit reticulocyte lysate (Pestova et al. 1996). Briefly, $826 \times 10^{6} \mathrm{HeLa}$ cells (IGBMC) were resuspended in $40 \mathrm{~mL}$ of lysis buffer $(15 \mathrm{mM}$ Tris- $\mathrm{HCl} \mathrm{pH} \mathrm{7.5,300}$ $\mathrm{mM} \mathrm{NaCl}, 6 \mathrm{mM} \mathrm{MgCl} 2,1 \%$ Triton X100) and incubated at $0^{\circ} \mathrm{C}$ for $20 \mathrm{~min}$. All the following steps were performed at $4^{\circ} \mathrm{C}$. Cell debris were removed by centrifugation at $6000 \mathrm{~g}$ for $1 \mathrm{~h}$. The supernatant was centrifuged at $45,000 \mathrm{rpm}$ in a Ti50.2 rotor (Beckman) for $5.5 \mathrm{~h}$. The ribosome pellet was resuspended in 6 $\mathrm{mL}$ buffer A (20 mM Tris- $\mathrm{HCl} \mathrm{pH} 7.5,50 \mathrm{mM} \mathrm{KCl}, 4 \mathrm{mM} \mathrm{MgCl}$, $2 \mathrm{mM}$ DTT, $250 \mathrm{mM}$ sucrose) and puromycin was added to the final concentration of $1 \mathrm{mM}$, and incubated for $10 \mathrm{~min}$ at $0^{\circ} \mathrm{C}$ then for $10 \mathrm{~min}$ at $37^{\circ} \mathrm{C}$ before addition of $\mathrm{KCl}$ to a final concentration of $500 \mathrm{mM}$. The solution was then centrifuged in a Ti50.2 rotor at $45,000 \mathrm{rpm}$ for $4.5 \mathrm{~h}$, yielding a pellet of ribosomes that was cleared from initiation and other cellular factors. Ribosomes were resuspended in buffer A supplemented with $500 \mathrm{mM} \mathrm{KCl}$ and resolved by centrifugation through a 10\%-30\% sucrose gradient in buffer A (+500 mM KCl) in SW32Ti rotor $(22,000$ rpm for $17 \mathrm{~h}, 100 \mathrm{~A}_{260}$ /tube). Gradients were fractionated in 1-mL fractions that were analyzed by electrophoretic migration on agarose gel. Fractions containing $40 \mathrm{~S}$ and $60 \mathrm{~S}$ were assembled separately and centrifuged at 130,000 rpm in S140AT rotor (Hitachi) for $2 \mathrm{~h}$. The resulting pellets of $40 \mathrm{~S}$ and $60 \mathrm{~S}$ subunits were resuspended in buffer $\mathrm{B}$ (20 mM Tris-HCl pH 7.5, 2 mM DTT, 2 mM MgCl, 100 $\mathrm{mM} \mathrm{KCl}, 250 \mathrm{mM}$ sucrose) for storage. In order to get pure $80 \mathrm{~S}$ subunits, a similar purification was performed with the exception of the dissociation step at $500 \mathrm{mM} \mathrm{KCl}$ that was omitted as well as the addition of $500 \mathrm{mM} \mathrm{KCl}$ in the sucrose gradient.

\section{Electrophoretic mobility shift assays (EMSA)}

To detect RNA-protein interactions by EMSA, recombinant NSP1 or pure human 40S, 60S, and $80 \mathrm{~S}$ ribosomal fractions were incubated with $50 \mathrm{fmol}$ of $5^{\prime 32} \mathrm{P}$-labeled RNA transcripts. Briefly, proteins and RNA were mixed with $20 \mu \mathrm{g}$ of yeast total tRNA (Merck Sigma-Aldrich) and incubated for $20 \mathrm{~min}$ in $10 \mathrm{mM}$ Tris- $\mathrm{HCl}(\mathrm{pH}$ 7.5), $50 \mathrm{mM} \mathrm{KCl}, 1 \mathrm{mM}$ DTT, $10 \%$ glycerol in $20 \mu \mathrm{L}$ at $0^{\circ} \mathrm{C}$. The RNA-protein complexes were analyzed by electrophoresis on na- tive $5 \%$ polyacrylamide gels using Tris-50 mM glycine as buffer system and visualized by phosphor imaging.

\section{SUPPLEMENTAL MATERIAL}

Supplemental material is available for this article.

\section{ACKNOWLEDGMENTS}

This work is funded by Agence Nationale pour la Recherche (ANR-17-CE12-0025-01, ANR-17-CE11-0024, ANR-20-COVI0078), Fondation pour la Recherche Médicale (project CoronalRES), Fondation Bettencourt Schueller, University of Strasbourg, and the Centre National de la Recherche Scientifique.

Received October 14, 2020; accepted November 29, 2020.

\section{REFERENCES}

Almeida MS, Johnson MA, Herrmann T, Geralt M, Wüthrich K. 2007. Novel $\beta$-barrel fold in the nuclear magnetic resonance structure of the replicase nonstructural protein 1 from the severe acute respiratory syndrome coronavirus. J Virol 81: 3151-3161. doi:10.1128/ JVI.01939-06

Andersen KG, Rambaut A, Lipkin Wl, Holmes EC, Garry RF. 2020. The proximal origin of SARS-CoV-2. Nat Med 26: 450-452. doi:10 .1038/s41591-020-0820-9

Banerjee AK, Blanco MR, Bruce EA, Honson DD, Chen LM, Chow A, Prashant B, Noah O, Quinodoz SA, Loney C, et al. 2020. SARSCoV-2 disrupts splicing, translation, and protein trafficking to suppress host defenses. Cell 183: 1325-1339.e21. doi:10.1016/j.cell .2020.10.004

Bouyssié D, Hesse AM, Mouton-Barbosa E, Rompais M, MacRon C, Carapito C, Gonzalez De Peredo A, Couté Y, Dupierris V, Burel A, et al. 2020. Proline: an efficient and user-friendly software suite for large-scale proteomics. Bioinformatics 36: 3148-3155. doi:10.1093/bioinformatics/btaa118

Brito Querido J, Sokabe M, Kraatz S, Gordiyenko Y, Skehel JM, Fraser CS, Ramakrishnan V. 2020. Structure of a human 48S translational initiation complex. Science 369: 1220-1227. doi:10.1126/ science.aba4904

Chan JFW, Kok KH, Zhu Z, Chu H, To KKW, Yuan S, Yuen KY. 2020. Genomic characterization of the 2019 novel human-pathogenic coronavirus isolated from a patient with atypical pneumonia after visiting Wuhan. Emerg Microbes Infect 9: 221-236. doi:10.1080/ 22221751.2020.1719902

Chicher J, Simonetti A, Kuhn L, Schaeffer L, Hammann P, Eriani G, Martin F. 2015. Purification of mRNA-programmed translation initiation complexes suitable for mass spectrometry analysis. Proteomics 15: 2417-2425. doi:10.1002/pmic.201400628

Filbin ME, Vollmar BS, Shi D, Gonen T, Kieft JS. 2013. HCV IRES manipulates the ribosome to promote the switch from translation initiation to elongation. Nat Struct Mol Biol 20: 150-158. doi:10 $.1038 / \mathrm{nsmb} .2465$

Fuchs G, Petrov AN, Marceau CD, Popov LM, Chen J, O'Leary SE, Wang R, Carette JE, Sarnow P, Puglisi JD. 2015. Kinetic pathway of $40 S$ ribosomal subunit recruitment to hepatitis $C$ virus internal ribosome entry site. Proc Natl Acad Sci 112: 319-325. doi:10 .1073/pnas.1421328111

Gibson DG, Young L, Chuang RY, Venter JC, Hutchison CA, Smith HO. 2009. Enzymatic assembly of DNA molecules up to 
several hundred kilobases. Nat Methods 6: 343-345. doi:10.1038/ nmeth.1318

Gray NK, Hentze MW. 1994. Iron regulatory protein prevents binding of the $43 \mathrm{~S}$ translation pre-initiation complex to ferritin and eALAS mRNAs. EMBO J 13: 3882-3891. doi:10.1002/j.1460-2075.1994 .tb06699.x

Hartenian E, Nandakumar D, Lari A, Ly M, Tucker JM, Glaunsinger BA. 2020. The molecular virology of coronaviruses running title: the molecular virology of coronaviruses. J Biol Chem 295: 1291012934. doi:10.1074/jbc.REV120.013930

Huang C, Lokugamage KG, Rozovics JM, Narayanan K, Semler BL, Makino S. 2011a. SARS coronavirus nsp1 protein induces template-dependent endonucleolytic cleavage of mRNAs: viral mRNAs are resistant to nsp1-induced RNA cleavage. PLoS Pathog 7: e1002433. doi:10.1371/journal.ppat.1002433

Huang C, Lokugamage KG, Rozovics JM, Narayanan K, Semler BL, Makino S. 2011b. Alphacoronavirus transmissible gastroenteritis virus nsp1 protein suppresses protein translation in mammalian cells and in cell-free HeLa cell extracts but not in rabbit reticulocyte lysate. J Virol 85: 638-643. doi:10.1128/JVI.01806-10

Jauregui AR, Savalia D, Lowry VK, Farrell CM, Wathelet MG. 2013. Identification of residues of SARS-CoV nsp1 that differentially affect inhibition of gene expression and antiviral signaling. PLOS One 8: e62416. doi:10.1371/journal.pone.0062416

Jimenez-Guardeño JM, Regla-Nava JA, Nieto-Torres JL, DeDiego ML, Castaño-Rodriguez C, Fernandez-Delgado R, Perlman S, Enjuanes L. 2015. Identification of the mechanisms causing reversion to virulence in an attenuated SARS-CoV for the design of a genetically stable vaccine. PLoS Pathog 11: e1005215. doi:10.1371/journal.ppat.1005215

Kamitani W, Narayanan K, Huang C, Lokugamage K, Ikegami T, Ito N, Kubo H, Makino S. 2006. Severe acute respiratory syndrome coronavirus nsp1 protein suppresses host gene expression by promoting host mRNA degradation. Proc Natl Acad Sci 103: 1288512890. doi:10.1073/pnas.0603144103

Kamitani W, Huang C, Narayanan K, Lokugamage KG, Makino S. 2009. A two-pronged strategy to suppress host protein synthesis by SARS coronavirus Nsp1 protein. Nat Struct Mol Biol 16: 1134-1140. doi:10.1038/nsmb.1680

Kim HT, Yin W, Jin YJ, Panza P, Gunawan F, Grohmann B, Buettner C, Sokol AM, Preussner J, Guenther S, et al. 2018. Myh10 deficiency leads to defective extracellular matrix remodeling and pulmonary disease. Nat Commun 9: 4600. doi:10.1038/s41467-018-06833-7

Kim D, Lee JY, Yang JS, Kim JW, Kim VN, Chang H. 2020. The architecture of SARS-CoV-2 transcriptome. Cell 181: 914-921.e10. doi:10.1016/j.cell.2020.04.011

Kumar A, Kumar A, Kumar P, Garg N, Giri R. 2020. SARS-CoV-2 NSP1 C-terminal region (residues 130-180) is an intrinsically disordered region. bioRxiv doi:10.1101/2020.09.10.290932

Lai MM, Stohlman SA. 1981. Comparative analysis of RNA genomes of mouse hepatitis viruses. J Virol 38: 661-670. doi:10.1128/JVI .38.2.661-670.1981

Lapointe CP, Grosely R, Johnson AG, Wang J, Fernández IS, Puglisi JD. 2020. Dynamic competition between SARS-CoV-2 NSP1 and mRNA on the human ribosome inhibits translation initiation. bioRxiv doi:10.1101/2020.08.20.259770

Lei L, Ying S, Baojun L, Yi Y, Xiang H, Wenli S, Zounan S, Deyin G, Qingyu $Z$, Jingmei $L$, et al. 2013. Attenuation of mouse hepatitis virus by deletion of the LLRKXGxKG region of Nsp1. PLoS One 8: e61166. doi:10.1371/journal.pone.0061166

Lei X, Dong X, Ma R, Wang W, Xiao X, Tian Z, Wang C, Wang Y, Li L, Ren $L$, et al. 2020. Activation and evasion of type I interferon responses by SARS-CoV-2. Nat Commun 11: 3810. doi:10.1038/ s41467-020-17665-9
Lokugamage KG, Narayanan K, Huang C, Makino S. 2012. Severe acute respiratory syndrome coronavirus protein nsp1 is a novel eukaryotic translation inhibitor that represses multiple steps of translation initiation. J Virol 86: 13598-13608. doi:10.1128/JVI.01958-12

Lu R, Zhao X, Li J, Niu P, Yang B, Wu H, Wang W, Song H, Huang B, Zhu N, et al. 2020. Genomic characterisation and epidemiology of 2019 novel coronavirus: implications for virus origins and receptor binding. Lancet 395: 565-574. doi:10.1016/S0140-6736(20) 30251-8

Martin F, Barends S, Jaeger S, Schaeffer L, Prongidi-Fix L, Eriani G. 2011. Cap-assisted internal initiation of translation of histone $\mathrm{H} 4$. Mol Cell 41: 197-209. doi:10.1016/j.molcel.2010.12.019

Martin F, Ménétret JF, Simonetti A, Myasnikov AG, Vicens Q, ProngidiFix L, Natchiar SK, Klaholz BP, Eriani G. 2016. Ribosomal 18S rRNA base pairs with mRNA during eukaryotic translation initiation. Nat Commun 7: 12622. doi:10.1038/ncomms 12622

Masters PS. 2006. The molecular biology of coronaviruses. Adv Virus Res 66: 193-292. doi:10.1016/S0065-3527(06)66005-3

Miao Z, Tidu A, Eriani G, Martin F. 2020. Secondary structure of the SARS-CoV-2 5'-UTR. RNA Biol 23: 1-10. doi:10.1080/15476286 .2020 .1814556

Nakagawa K, Lokugamage KG, Makino S. 2016. Viral and cellular mRNA translation in coronavirus-infected cells. AdvVirus Res 96: 165-192. doi:10.1016/bs.aivir.2016.08.001

Narayanan K, Huang C, Lokugamage K, Kamitani W, Ikegami T, Tseng C-TK, Makino S. 2008. Severe acute respiratory syndrome coronavirus nsp1 suppresses host gene expression, including that of type I interferon, in infected cells. J Virol 82: 4471-4479. doi:10.1128/JVI.02472-07

Otterpohl KL, Busselman BW, Ratnayake I, Hart RG, Hart K, Evans C, Phillips CL, Beach JR, Ahrenkiel P, Molitoris B, et al. 2020. Conditional Myh9 and Myh10 inactivation in adult mouse renal epithelium results in progressive kidney disease. $\mathrm{JCl}$ Insight 5: 138530. doi:10.1172/jci.insight.138530

Pestova TV, Hellen CU, Shatsky IN. 1996. Canonical eukaryotic initiation factors determine initiation of translation by internal ribosomal entry. Mol Cell Biol 16: 6859-6869. doi:10.1128/MCB.16.12.6859

Prongidi-Fix L, Schaeffer $L$, Simonetti A, Barends S, Ménétret J-F, Klaholz BP, Eriani G, Martin F. 2013. Rapid purification of ribosomal particles assembled on histone H4 mRNA: a new method based on mRNA-DNA chimaeras. Biochem J 449: 719-728. doi:10 .1042/BJ20121211

Quade N, Boehringer D, Leibundgut M, van den Heuvel J, Ban N. 2015. Cryo-EM structure of hepatitis $C$ virus IRES bound to the human ribosome at 3.9-Å resolution. Nat Commun 6: 7646. doi:10 $.1038 /$ ncomms 8646

Rangan R, Zheludev IN, Das R. 2020. RNA genome conservation and secondary structure in SARS-CoV-2 and SARS-related viruses: a first look. RNA 26: 937-959. doi:10.1261/rna.076141.120

Rao S, Hoskins I, Daniela Garcia P, Tonn T, Ozadam H, Cenik S, Cenik C. 2020. Genes with 5' terminal oligopyrimidine tracts preferentially escape global suppression of translation by the SARSCoV-2 NSP1 protein. bioRxiv doi:10.1101/2020.09.13.295493

Schubert K, Karousis ED, Jomaa A, Scaiola A, Echeverria B, Gurzeler LA, Leibundgut M, Thiel V, Mühlemann O, Ban N. 2020. SARS-CoV-2 Nsp1 binds the ribosomal mRNA channel to inhibit translation. Nat Struct Mol Biol 27: 959-966. doi:10.1038/ s41594-020-0511-8

Shi M, Wang L, Fontana P, Vora S, Zhang Y, Fu T-M, Lieberman J, Wu H. 2020. SARS-CoV-2 Nsp1 suppresses host but not viral translation through a bipartite mechanism. bioRxiv doi:10.1101/2020 09.18.302901

Sola I, Almazán F, Zúñiga S, Enjuanes L. 2015. Continuous and discontinuous RNA synthesis in coronaviruses. Annu Rev Virol 2: 265288. doi:10.1146/annurev-virology-100114-055218 
Tanaka T, Kamitani W, DeDiego ML, Enjuanes L, Matsuura Y. 2012. Severe acute respiratory syndrome coronavirus nsp 1 facilitates efficient propagation in cells through a specific translational shutoff of host mRNA. J Virol 86: 11128-11137. doi:10.1128/JVI.0170012

Thoms $M$, Buschauer $R$, Ameismeier $M$, Koepke $L$, Denk $T$, Hirschenberger $M$, Kratzat $H$, Hayn $M$, Mackens-Kiani $T$, Cheng J, et al. 2020. Structural basis for translational shutdown and immune evasion by the Nsp1 protein of SARS-CoV-2. Science 369: 1249-1255. doi:10.1126/science.abc8665

Tohya Y, Narayanan K, Kamitani W, Huang C, Lokugamage K, Makino S. 2009. Suppression of host gene expression by nsp 1 proteins of group 2 bat coronaviruses. J Virol 83: 5282-5288. doi:10 $.1128 / J V I .02485-08$

Wathelet MG, Orr M, Frieman MB, Baric RS. 2007. Severe acute respiratory syndrome coronavirus evades antiviral signaling: role of nsp1 and rational design of an attenuated strain. J Virol 81: 11620-11633. doi:10.1128/JVI.00702-07

Wu C, Liu Y, Yang Y, Zhang P, Zhong W, Wang Y, Wang Q, Xu Y, Li M, $\mathrm{Li} X$, et al. 2020. Analysis of therapeutic targets for SARS-CoV-2 and discovery of potential drugs by computational methods. Acta Pharm Sin B 10: 766-788. doi:10.1016/j.apsb.2020.02.008

Xia H, Cao Z, Xie X, Zhang X, John Yun-Chung C, Wang H, Menachery VD, Rajsbaum R, Shi P-Y. 2020. Evasion of type-l inter- feron by SARS-CoV-2. Cell Rep 33: 108234. doi:10.1016/j.celrep 2020.108234

Yamamoto H, Collier M, Loerke J, Ismer J, Schmidt A, Hilal T, Sprink T, Yamamoto K, Mielke T, Bürger J, et al. 2015. Molecular architecture of the ribosome-bound hepatitis $C$ Virus internal ribosomal entry site RNA. EMBO J 34: 3042-3058. doi:10.15252/embj .201592469

Yogo Y, Hirano N, Hino S, Shibuta H, Matumoto M. 1977. Polyadenylate in the virion RNA of mouse hepatitis virus. J Biochem 82: 1103-1108. doi:10.1093/oxfordjournals.jbchem.a131782

Yokoyama T, Machida K, Iwasaki W, Shigeta T, Nishimoto M, Takahashi M, Sakamoto A, Yonemochi M, Harada Y, Shigematsu $\mathrm{H}$, et al. 2019. HCV IRES captures an actively translating $80 \mathrm{~S}$ ribosome. Mol Cell 74: 1205-1214. doi:10.1016/j.molcel .2019.04.022

Zhou P, Yang XL, Wang XG, Hu B, Zhang L, Zhang W, Si HR, Zhu Y, Li B, Huang $C L$, et al. 2020. A pneumonia outbreak associated with a new coronavirus of probable bat origin. Nature 579: 270 273. doi:10.1038/s41586-020-2012-7

Züst R, Cervantes-Barragán L, Kuri T, Blakqori G, Weber F, Ludewig B, Thiel V. 2007. Coronavirus non-structural protein 1 is a major pathogenicity factor: implications for the rational design of coronavirus vaccines. PLoS Pathog 3: e109. doi:10.1371/journal.ppat .0030109 

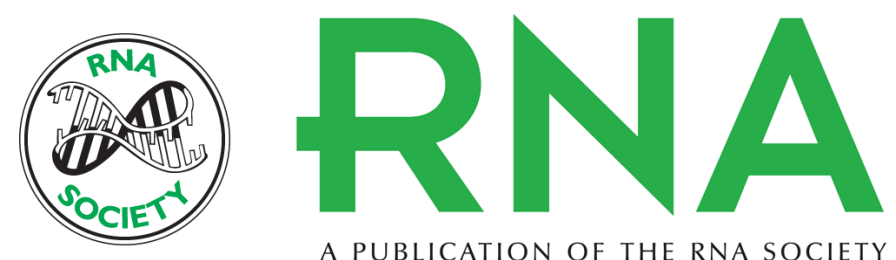

A PUBLICATION OF THE RNA SOCIETY

\section{The viral protein NSP1 acts as a ribosome gatekeeper for shutting down host translation and fostering SARS-CoV-2 translation}

Antonin Tidu, Aurélie Janvier, Laure Schaeffer, et al.

RNA 2021 27: 253-264 originally published online December 2, 2020

Access the most recent version at doi:10.1261/rna.078121.120

\section{Supplemental http://rnajournal.cshlp.org/content/suppl/2020/12/02/rna.078121.120.DC1 Material}

References This article cites 53 articles, 20 of which can be accessed free at: http://rnajournal.cshlp.org/content/27/3/253.full.html\#ref-list-1

Open Access Freely available online through the RNA Open Access option.

Creative This article, published in $R N A$, is available under a Creative Commons License Commons (Attribution-NonCommercial 4.0 International), as described at License http://creativecommons.org/licenses/by-nc/4.0/.

Email Alerting Receive free email alerts when new articles cite this article - sign up in the box at the Service top right corner of the article or click here.

\section{|||||||| Providing Precise Solutions for your research.}

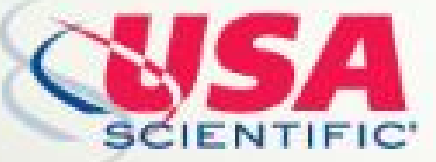

To subscribe to $R N A$ go to:

http://rnajournal.cshlp.org/subscriptions

(C) 2021 Tidu et al.; Published by Cold Spring Harbor Laboratory Press for the RNA Society 